\title{
Erratum to: Water Policy in Mexico
}

\author{
Hilda R. Guerrero García Rojas
}

\section{Erratum to:}

H. R. Guerrero García Rojas (ed.), Water Policy in Mexico, Global Issues in Water Policy 20, https://doi.org/10.1007/978-3-319-76115-2

The book was inadvertently published with incorrect year, 2018, in the citations and references of cross-references made to the chapters published in this book. This has been corrected as 2019 in Chapters 1 and 5 .

\footnotetext{
The updated online version of these chapters can be found at https://doi.org/10.1007/978-3-319-76115-2_1

https://doi.org/10.1007/978-3-319-76115-2_5

https://doi.org/10.1007/978-3-319-76115-2
} 